\title{
Rua Governador Sampaio: cinema, cidade e trabalho
}

\author{
Rodrigo Capistrano*
}

Palavras-chave:
Cinema
Cidade
Trabalho

Keywords:

Cinema

City

Work
Resumo: Rua Governador Sampaio é um filme documentário que registra, no período de um dia, a rotina de uma das mais movimentadas ruas do centro da cidade de Fortaleza. O referido lugar abriga principalmente depósitos de mercadorias, além de grandes e pequenas lojas que destinam seus produtos para a venda no atacado. A partir da análise do filme, colocaremos em diálogo a cidade e o trabalho, refletindo sobre algumas transformações urbanas recentes da capital cearense.

Abstract: Rua Governador Sampaio is a documentary film that records, within one day, routine of one of the busiest downtown streets of the city of Fortaleza. That place mainly houses deposits of goods, as well as large and small shops designed their products for sale wholesale. From the analysis of the film we will put in dialogue the city and the work, reflecting on some recent urban transformations of Fortaleza.

Recebido em 31 de outubro de 2016. Aprovado em 17 de fevereiro de 2017.

\section{Preâmbulo: a cidade e o cinema}

[..] a cidade foi, desde cedo, reduto de uma nova sensibilidade. Ser citadino, portar um "ethos" urbano,

pertencer a uma cidade implicou formas, sempre renovadas ao longo do tempo, de representar essa cidade, fosse pela palavra, escrita ou falada, fosse pela música, em melodias e canções que a celebravam, fosse pelas imagens, desenhadas, pintadas ou projetadas, que a representavam, no todo ou em parte, fosse ainda pelas práticas cotidianas, pelos rituais e pelos códigos de civilidade presentes naqueles que a habitavam. Às cidades reais, concretas, visuais, tácteis, consumidas e usadas no dia a dia, corresponderam outras tantas cidades imaginárias, a mostrar que o urbano é bem a obra máxima do homem, obra esta que ele não cessa de reconstruir, pelo pensamento e pela ação, criando outras tantas cidades, no pensamento e na ação, ao longo dos séculos.

Pesavento (2007, p. 11).

Em suas práticas e vivências urbanas, os indivíduos sempre procuraram desenvolver mecanismos variados para sentir e representar as cidades. Podemos exponenciar ainda mais essa afirmação se delimitarmos o período histórico a partir das grandes transformações proporcionadas pelo capitalismo industrial. Esse modelo de cidade conheceu inúmeras reações dos sujeitos na ordem do sensível, onde problematizar o espaço urbano acabou sendo a tônica da obra de grandes artistas, pensadores e filósofos. Em meio ao caos urbano, muitos preferiram identificar a cidade como um vetor que convergia para a solidão e o individualismo. Raymond Williams (1989, p. 316), partindo das leituras de nomes importantes da literatura ocidental que pensaram a cidade, como Baudelaire, Balzac, Dostoievski e Dickens, afirmou que: "[...] o caráter social da cidade - no que tem de transitório, inesperado, na procissão de homens e eventos, e no isolamento essencial e inebriante - era visto como a realidade de toda existência humana".

O cinema também sempre se preocupou em retratar o surgimento das metrópoles. Ainda nas primeiras décadas da sua história, importantes trabalhos foram realizados com o intuito de mostrar a rotina das grandes cidades pelo mundo. Se voltarmos aos filmes da segunda metade dos anos 1920 do século passado, identificaremos as chamadas "sinfonias da cidade", marcos da história do cinema. Nelas, destacamos o seguinte conjunto de obras: Rien que les heures (1926), 
do brasileiro Alberto Cavalcanti, mostrando Paris, foi o considerado precursor desses filmes; Berlin, Sinfonia da Metrópole (1927), de Walther Ruttmann, é o mais reconhecido e ilustrativo dentro dessa referida proposta fílmica; $\mathrm{O}$ homem com uma câmera, de Dziga Vertov, retratando algumas cidades soviéticas, principalmente Moscou, foi o mais admirado com o passar das décadas pela ousadia estética empreendida pelo realizador; São Paulo, Sinfonia da Metrópole (1929), dos cineastas húngaros Rodolfo Lustig e Adalberto Kemeni, inspirado principalmente no filme de Ruttmann, é um clássico nacional do cinema mudo.

$\mathrm{Na}$ maioria das vezes, os realizadores dos clássicosfilmescitadosilustravamodesenvolvimento econômico e as grandes transformações estruturais que as cidades enfrentavam. Existia um efusivo sentimento de grandiosidade e progresso, em uma realidade que eles tinham acabado de se deparar. O filme que iremos analisar, Rua Governador Sampaio (2009), do diretor e fotógrafo Victor de Melo, poderia ter optado por esse caminho. A cidade de Fortaleza também teve um progresso vertiginoso nas últimas décadas. Porém, essa associação não é assim tão óbvia. Os realizadores optaram por produzir um documentário de observação que desenvolve um olhar paciente e generoso acerca de uma rua homônima ao título do filme, respeitando suas variações e múltiplos tempos. O cineasta russo Andrei Tarkovsky (1998, p. 139) assim descreveu as sensações de apreensão do tempo nas imagens:

De que modo o tempo se faz sentir
numa tomada? Ele se torna perceptível
quando sentimos algo de significativo
e verdadeiro, que vai além dos
acontecimentos mostrados na tela;
quando percebemos, com clareza, que
aquilo que vemos no quadro não se
esgota em sua configuração visual, mas
é indício de alguma coisa que se estende
para além do quadro, para o infinito:
um indício de vida.

Rua Governador Sampaio desenvolve uma linha semelhante à descrita, na apresentação daquele lugar, em uma detalhada observação, mesclando desde a frenética correria do cotidiano até a valorização de alguns traços minimalistas realizados na sua construção. Entre as mais fortes semelhanças com os chamados filmes da sinfonia das cidades, temos a prévia demarcação temporal. Se em Berlim, Sinfonia da Metrópole, o diretor Walther Ruttmann apresenta a cidade em um suposto período de um dia, iniciando seu filme no amanhecer com a chegada do trem e terminando com a explosão dos fogos de artifício na madrugada de uma agitada vida noturna, Victor de Melo dá início ao seu percurso na Rua Governador Sampaio com a abertura do comércio e a chegada de mercadorias no começo do dia. Será no final da tarde, nos primeiros sinais da noite que se anuncia, que a caminhada do filme chegará ao fim. Nessas sequências, limitadas pelo arco temporal que aproxima os planos de abertura do filme e o seu fechamento, percebemos a referência mais direta às chamadas sinfonias da cidade das vanguardas nos anos 1920 .

Victor de Melo realiza uma espécie de cartografia de sensações daquele lugar, ativando a dimensão produtiva do presente, mas também operando e se relacionando com o passado em suas múltiplas tessituras. Isso se aproxima com a reflexão estabelecida pelo filósofo Giorgio Agamben (2009, p. 21) sobre o que seria o contemporâneo:

Pertence realmente ao seu tempo, é verdadeiramente contemporâneo aquele que não coincide perfeitamente com aquele, nem se adequa a suas pretensões e é, portanto, nesse sentido, inatual. Mas, justamente por isso, a partir desse afastamento e desse anacronismo, é mais capaz do que os outros de perceber e de apreender o seu tempo.

Rua Governador Sampaio seria, portanto, um filme contemporâneo a partir dessa relação de aproximação e distanciamento com o tempo vivido. Não buscando uma adesão absoluta para os problemas e questões do presente, mas observando uma determinada realidade para também assumir um desejo de mudança e de criação sobre esse tempo. A cidade que se apresenta como um produto de experiências individuais e coletivas não tem com este filme a representação do real, mas acaba inserindo realizadores, personagens e espectadores 
na experiência em um determinado real de um microcosmo urbano.

\section{A rua, o cinema e o trabalho}

A cidade não conta o seu passado, ela o contém como as linhas das mãos, escritas em ângulos das ruas, nas grades das janelas, nos corrimãos das escadas, nas antenas dos para-raios, nos mastros das bandeiras, cada segmento riscado por arranhões, serradelas, entalhes, esfoladuras.

Calvino (1990, p. 12).

Rua Governador Sampaio ${ }^{1}$ é um curtametragem que registra o dia a dia de uma das mais movimentadas ruas do centro da cidade de Fortaleza. O referido espaço abriga principalmente depósitos de mercadorias, além de grandes e pequenas lojas que destinam seus produtos para a venda no atacado. A rua integra uma área de algumas quadras que possui um fluxo intenso de pessoas, envolvendo comerciantes, consumidores, trabalhadores e moradores, e de mercadorias, destacando-se principalmente gêneros alimentícios, bebidas, plásticos, tecidos e miudezas em geral.

A estreita rua serve de estacionamento para caminhões que a todo o momento embarcam e desembarcam grande quantidade de mercadorias, e as diminutas calçadas são disputadas pelo amontoado de produtos que se instalam, pelos carregadores com seu passo apressado e os passantes que ali transitam. A desorganização do tráfego, a ocupação desordenada da área, além do descaso e abandono do poder público na preservação e nos cuidados com o local, já data de algumas décadas. Situação essa que tem jogado a região em um completo abandono, sendo destacada a precária infraestrutura dos estabelecimentos comerciais e as reclamações de insegurança, seja nos costumeiros assaltos noturnos ou até mesmo nos riscos de incêndios algumas vezes observados em depósitos com pouca ou nenhuma manutenção ${ }^{2}$.

Diante dos problemas mencionados, nos últimos anos tivemos o fechamento de algumas lojas desse mercado atacadista. Isso fez com que, apesar de continuar o foco de atividades voltadas para o comércio, a rua também passasse a desenvolver uma área residencial um pouco maior. Pequenos prédios antigos que já serviram de lojas e depósitos, hoje abrigam famílias que pagam aluguéis mais baratos que outras regiões vizinhas. Apesar da comentada agitação do lugar acontecer principalmente durante o horário comercial de segunda à sexta, já é comum encontrar outra rotina e ocupações em dias e horários variados da semana.

Esse movimento descrito fica instalado em uma área histórica da cidade. Nos arredores da Rua Governador Sampaio, ficam instalados prédios importantes, tais como: a Catedral, em seu estilo gótico imponente, o Paço Municipal, principal sede da Prefeitura e outras secretarias, e o Mercado Central, importante ponto turístico que abriga parte do artesanato local. Além deles, poderíamos mencionar dezenas de outros prédios, praças e igrejas importantes da cidade que também se localizam bem próximos dali, sendo a rua, ao mesmo tempo, uma espécie de rota de passagem para locais históricos e turísticos, além de um nervoso epicentro comercial do centro da cidade de Fortaleza.

Todo esse universo chamou a atenção de Victor de Melo, morador desde a infância do Poço da Draga, comunidade da Praia de Iracema, muito próximo do centro da cidade. Essa localidade fica na região do antigo porto de Fortaleza ${ }^{3}$. Situa-se à beira-mar ao lado da chamada Ponte Metálica e, onde antes existiam armazéns que guardavam trilhos de ferro e barris de combustíveis, vivem hoje mais de 2 mil pessoas. A comunidade é constantemente ameaçada pelo poder público de desalojamento para a concretização de reformas que potencializem o turismo na região. Diante disso, os moradores têm, nos últimos anos, demonstrado grande poder de organização ao articularem várias ações de cultura e resistência. Victor cresceu na comunidade e teve a sua formação em audiovisual ligado aos cursos da ONG Alpendre ${ }^{4}$ e da Escola de Audiovisual de Fortaleza da Vila das Artes ${ }^{5}$.

Neste contexto, o diretor sempre teve a Rua Governador Sampaio como uma de suas vizinhas. Melhor explicando, a rua sempre esteve presente na sua vivência como uma rota de passagem da sua casa para o centro comercial de Fortaleza, recorte espacial fortemente ligada ao seu universo 
de reconhecimento. O primeiro curta-metragem de Victor de Melo foi Casa da Vovó (2008), um registro pessoal e afetivo de um dia na casa da sua avó, moradora do Poço da Draga, onde são reconstituídos traços da sua memória pessoal e de sua família. Rua Governador Sampaio foi realizado logo depois. Nesses dois projetos citados, percebemos o quanto Victor de Melo busca a concretização de um cinema que ultrapassa os limites da observação de uma realidade qualquer. Seus documentários se mostram como a afirmação e a busca de um mundo em que ele guarda uma relação de familiaridade e pertencimento ${ }^{6}$.

Seja contemplando e participando da interioridade do espaço íntimo e doméstico em Casa da Vovó ou desenvolvendo um olhar curioso e apurado para a exterioridade daquele espaço agitado de trabalho em Rua Governador Sampaio, Victor de Melo quer descobrir seu próprio mundo. Olhar para o cotidiano é buscar percebê-lo de outras maneiras, naquilo que lhe pertence e ao mesmo tempo não se conhece, em uma intricada relação entre vida e representação. Esse parece ser o caminho adotado no seu trabalho autoral até o presente momento, uma prática documental que parte de um desejo em mergulhar com afinco naquilo que o cerca e o que lhe diz respeito, algo muito próximo daquilo que nos afirmou Jean-Louis Comolli (2008, p. 169):

A prática do cinema documentário não depende, em última análise, nem dos circuitos de financiamento nem das possibilidades de difusão, mas simplesmente da boa vontade - da disponibilidade - de quem ou daquilo que escolhemos para filmar: indivíduos, instituições, grupos. O desejo está no posto do comando. As condições da experiência fazem parte da experiência.

Ainda nessa chave de interpretação, lembramos que em Rua Governador Sampaio Victor de Melo optou por estabelecer o seguinte dispositivo: a câmera está sempre localizada no interior das residências e das lojas, onde a rua é visualizada de dentro pra fora, estabelecendo uma relação de maior cumplicidade do realizador com as pessoas filmadas. Esse rigor continua inclusive dentro dos caminhões, onde a câmera é colocada algumas vezes na boleia, com uma visão de quem é passageiro, outras no baú interior das carretas, ao lado das mercadorias e sempre acompanhando de forma atenta a árdua atividade dos trabalhadores. Os comerciantes e moradores que abriram suas portas para concretizar esse dispositivo fílmico também desenvolvem essa vontade de colaborar, de estabelecer essa relação de confiança com Victor de Melo e sua equipe, em um desejo aberto e transpassado pelo mundo, construção de possíveis a partir da relação estabelecida entre realizador e indivíduos filmados.

A Rua Governador Sampaio no passado já foi conhecida pelo nome de "Beco da apertada hora", nada mais sugestivo para essa rua pequena e estreita, geralmente apressada e apertada. Reclamações de toda a ordem já surgiram nas últimas décadas para transferir ou reestruturar aquela região de comércio atacadista. Mas aquela situação de abandono, de sujeira, de poluição visual e sonora continua a perdurar, parecendo já fazer parte da paisagem daquele pedaço do centro da cidade:

São muitas as campanhas orientadas no sentido de transferir o comércio atacadista do centro da cidade. Tratase de movimentos que se apoiam no argumento do difícil transbordo de cargas daquela área. Sem dúvida nenhuma, é inusitado verificar o número de carretas que trafegam com dificuldade na estreita rua e em suas imediações. Ali vemos carregadores com seus carrinhos e outros que pegam enormes sacas cheias de cereais ou caixas de mercadorias, carregando ou descarregando, enchendo ou esvaziando galpões estreitos e profundos. A sonoridade marca olugar. É diferente. Ecoam os gritos desses trabalhadores cumprimentando seus companheiros ou pedindo passagem. Abrem caminho empurrando os sacos sobre os transeuntes desavisados, observadores ocasionais desatentos que atrapalham a faina diária desses homens ágeis e musculosos. Em plena rua, pessoas simples catam as perdas dos pesados sacos. Buscam garantir a ração mínima. (BORZACCHIELLO, 2010). 
A questão da especificidade sonora do lugar também foi trabalhada pela equipe de Rua Governador Sampaio. Esse espaço já sugere a presença de alguns elementos esperados: os motores e buzinas dos automóveis, o barulho das velhas portas de aço abrindo e fechando as lojas, o já citado burburinho de conversas e gritos que pedem passagem na rua. $\mathrm{O}$ som de alguns objetos também direciona a atenção dos espectadores, como o telefone que toca, a escada sendo arrastada e o funcionamento de tipos variados de ventiladores nos estabelecimentos. Porém, a experiência auditiva mais curiosa é possibilitada pelo rádio e pela televisão.

Referimo-nos, principalmente, às sequências em que Rua Governador Sampaio se volta para o interior das residências. Quando uma jovem sobe as escadas de um prédio escutamos um reggae. Já dentro do espaço, uma criança olha para a câmera e rapidamente começamos a conhecer melhor o ambiente. Uma caixa de isopor pendurada em uma prateleira na parte superior do quadro na imagem anuncia por escrito: "salgados e sucos 1,00 real". Embaixo dela, uma cozinha onde quatro ou cinco pessoas realizam a atividade conjunta de preparar os salgados. Ao som de Bob Marley: a massa dos produtos é confeccionada; um rapaz apanha a última fornalha pronta; pratos e utensílios de cozinha são lavados; uma mulher manuseia um celular, escolhendo o melhor ângulo para capturar uma foto ou fazer um vídeo; uma criança é embalada nos braços da mãe; uma jovem dança.

Nossa atenção é conduzida para outro ambiente fechado pelo som emitido por um aparelho de televisão. $\mathrm{Na}$ sala, um jovem está sentado em uma rede com um pequeno cachorro em seus braços. Enquanto acompanhamos a brincadeira dos dois, podemos identificar o som da televisão. Trata-se provavelmente de um desenho animado. O próximo espaço é apresentado juntamente com um funk. No plano, uma criança se apoia no canto de uma cama ajoelhada no chão. Seu olhar está fixo para alguma coisa fora de quadro. Um jovem entra no ambiente e logo se junta à criança. Na televisão, é exibido um show da funkeira Andressa Soares, conhecida como a Mulher Melancia. O som da música é agora ouvido em um volume mais elevado. $\mathrm{O}$ plano seguinte é de uma janela aberta. $\mathrm{O}$ som anterior da música aos poucos vai se misturando ao som da rua, até ser totalmente substituído. Ouvimos o barulho do motor de uma carreta e alguns breves gritos de alerta são pronunciados. Depois, o forte sinal sonoro de um sensor de estacionamento para caminhões é emitido. Então, somos conduzidos novamente para um plano externo.

Concluímos que essas passagens conduzidas pelo som são fundamentais para o desenvolvimento da própria narrativa do filme, guiando nossa percepção espaço-temporal. A única sequência externa em que um som de rádio é novamente identificado desempenha até certa função sensorial. São momentos ocorridos logo depois do almoço, dentro da boleia de um caminhão. Ao som de Sunshine on my shoulders, clássico de John Denver dos anos 1970, a câmera capta três rápidos planos: duas pessoas sentadas na calçada observam o movimento da rua, um senhor cochila ao longe e alguns amigos conversam animadamente ao lado de um vendedor de CD pirata, provavelmente o lugar de origem da música. Com exceção do ambulante, todas as pessoas que aparecem nessa sequência estão no seu momento de descanso após o almoço, períodos de sesta, conversas e lazer nos intervalos de trabalho.

Jacques Rancière, analisando a correspondência de dois operários ingleses no século XIX, pretendendo encontrar informações sobre a condição e as formas de consciência dos trabalhadores naquele tempo, depois de acompanhar os referidos escritos teve uma grande surpresa:

Estes trabalhadores que supostamente deviam fornecer-me informações sobre as condições do trabalho e as formas de consciência de classe ofereciam-me uma coisa completamente diferente: o sentimento de uma parecença, uma demonstração da igualdade. Também eles eram espectadores e visitantes no seio da sua própria classe. A actividade [sic] de propaganda que era a sua, não podia separar-se dos seus ócios de passeantes e de indivíduos entregues à contemplação. A simples crônica dos 
seus ócios obrigava a reformular as relações estabelecidas entre ver, fazer e falar. Tornando-se espectadores e visitantes, alteravam completamente a partilha do sensível que pretende que os que trabalham não dispõem de tempo para deixar correr ao acaso os seus passos e os seus olhares e que os membros de um corpo colectivo [sic], não têm tempo para consagrar às formas e aos sinais da individualidade. É este o significado da palavra emancipação: desmantelar a fronteira entre os que agem e os que vêem $[s i c]$, entre indivíduos e membros de um corpo colectivo [sic]. Aqueles dias, assim passados, não ofereciam aos dois correspondentes e aos seus semelhantes um saber acerca da sua condição e a energia necessária para o trabalho da semana seguinte ou para a luta subsequente. Ofereciam-lhes, sim, a reconfiguração aqui e agora da repartição do espaço e do tempo, do trabalho e do ócio. (RANCIÈRE, 2010, p. 30-31).

Rua Governador Sampaio também se propõe a falar das condições de trabalho daquelas pessoas. Mas o filme vai além quando apresenta as contradições que emanam daquele espaço, visto que complexifica as antigas repartições entre ócio e trabalho, buscando tempos e indivíduos outros que não sejam apenas aqueles pautados em uma tipificação. Na sequência na cozinha ao som de reggae, anteriormente descrita, trabalho e lazer coexistem, elementos indissociáveis que esgarçam as fronteiras outrora limitadas pelas lentes da sociedade disciplinar.

Outra sequência da obra de Victor de Melo que pudemos identificar momentos de lazer é mais um dos percursos da câmera em um espaço fechado, onde vemos alguns homens envolvidos em um jogo de cartas. A janela da sala aberta sugere que a rua segue seu ritmo normal na rotina de comércio e agitação. Porém, naquele ambiente, os homens estão mais preocupados com o carteado. Não sabemos muito sobre o espaço em que se desenrola a cena. A presença de outra mesa vazia próxima aos jogadores, bem como de garrafas de café e utensílios de cozinha, sugere que aquele apartamento serve como pequeno restaurante ou ponto de apoio para os trabalhadores exercerem suas pausas. Coube ao próprio cineasta e sua equipe estabelecer uma relação reflexiva com aquele ambiente, visitantes temporários daquele microuniverso urbano.

A maior parte da construção narrativa de Rua Governador Sampaio acompanha a rotina de um dia comum de trabalho daquele espaço. $\mathrm{O}$ barulho das portas de aço abrindo as lojas no início do dia é o primeiro som que identificamos no filme, introduzido, ainda sob a tela preta, juntamente com a entrada do título. Em pouco mais da metade dos apenas 13 minutos de duração da obra, acompanhamos um bloco de imagens que identifica a "hora do almoço". Na Rua Governador Sampaio e seu entorno, são muitos os pequenos restaurantes, bares e lanchonetes. Alguns deles servem "pratos feitos" ou fornecem "quentinhas" para abastecer o grande número de pessoas que transitam na região. Isso também garante agilidade na hora da refeição, sendo essa a sensação que temos ao acompanhar aquelas imagens. São inúmeros planos rápidos e cortes abruptos. Aliás, essa é outra importante estratégia de montagem do filme: o ritmo interno da duração dos planos também segue a correria do dia. Mas, talvez, em nenhuma hora isso seja tão evidente quanto no momento do almoço. Esse processo de edição foi decisivo para que o filme ganhasse alguns contornos, para que determinadas escolhas pudessem ser realizadas ${ }^{8}$. Trata-se de uma obra em processo aberto, uma forma de olhar para determinados espaços que a todo o momento vão se desdobrando e se multiplicando.

Uma seleção de planos mais próximos do final de Rua Governador Sampaio nos apresenta imagens captadas dentro do baú dos caminhões e de alguns depósitos de mercadorias. No primeiro deles, vemos despontar - por trás de grandes sacas de cereais acondicionadas no referido veículo as torres da Catedral de Fortaleza. A partir daí, sucedem-se vários planos, seguindo a aceleração da já comentada montagem. Em um dado momento, depois de toda aquela movimentação de produtos transportados e sacas de mercadorias sendo reorganizadas, o ritmo das imagens é quebrado: durante três segundos um trabalhador fica parado, escorado na saída do baú do caminhão, com o 
olhar fixo para a câmera, destruindo de forma abrupta a transparência da presença da equipe. A presença daquele olhar consciente dura muito pouco tempo, mas o suficiente para gerar toda uma gama de implicações de forma e conteúdo dentro da narrativa. A partir dessa intermediação, o sujeito filmado se transporta para a condição de espectador ou, retomando as palavras de Rancière (2010), ele também se transforma em visitante no seio da sua própria classe.

Essa dimensão política de Rua Governador Sampaio continuará nas próximas imagens. Depois de uma rápida sucessão de planos, uma nova estratégia de montagem será lançada, encerrando a sequência: no baú do caminhão, o carregador arremessa mais uma saca de mercadoria. Nesse momento, o som é suprimido e as imagens ficam em câmera lenta. A repetição dos planos e o destaque nos fragmentos do corpo do trabalhador chamam nossa atenção de forma preeminente. $\mathrm{O}$ suor que dali escorre ganha ainda mais ênfase com o retorno do som. O barulho da água da chuva vai aumentando, até que somos mais uma vez conduzidos para uma sequência externa a partir de uma montagem sonora.

A chuva que cai pesada modifica a rotina da Rua Governador Sampaio, ganhando novos contornos. Alguns transeuntes se protegem com caixas de papelão, o trabalho tradicional de embarque e desembarque de produtos é impossibilitado, pessoas sentam na calçada para contemplar a ação da natureza. Terminada a chuva, a câmera retorna mais uma vez para a boleia de um caminhão. Em um mesmo ângulo baixo, podemos observar uma pequena águia de plástico posicionada no painel do veículo e os pombos lá fora, pendurados nos fios de alta tensão dos postes de iluminação. $O$ céu, ainda um pouco nublado, parece indicar que a tarde vai se aproximando do seu fim, uma carroça abarrotada de mercadorias passa no quadro, alguns pássaros voam, um $z$ oom-in ${ }^{9}$ desloca rapidamente a imagem em direção aos pombos, o adereço da águia de plástico é vista agora de maneira centralizada no plano. Esse último elemento encerra o filme, em meio a muito barulho de motores e buzinas. Findado mais um dia de trabalho, a Rua Governador Sampaio segue seu curso.

\section{Notas}

1 O filme está disponível em: <https://www.youtube. com/watch?v=a4PHgzZpTvI $>$.

2 Nas últimas décadas, já foram registrados casos de incêndios em vários pontos do centro da cidade de Fortaleza. Na Rua Governador Sampaio, o último aconteceu em setembro de 2008, destruindo quase por completo um prédio onde funcionavam duas lojas: uma de plásticos e outra de cereais.

3 O Poço da Draga é a principal localidade do bairro da Praia de Iracema, completando 110 anos de existência em 2016. Segundo dados do Censo de 2010, a comunidade possui uma população de 2.029 pessoas vivendo em 505 unidades domiciliares. Isso corresponde a quase $65 \%$ das pessoas que residem na Praia de Iracema atualmente (DIÁRIO DO NORDESTE, 2014).

4 O Alpendre - Casa de arte, pesquisa e produção foi uma Organização Não Governamental localizada na Praia de Iracema que desenvolveu um importante espaço de pensamento e produção artística na cidade de Fortaleza durante os seus 12 anos de funcionamento (2000-2012). Oferecendo seus primeiros cursos de formação em audiovisual para os jovens do Poço da Draga, desenvolveu, a partir de 2003 o projeto NoAr, que consistia na realização de um programa veiculado na TV pública do estado do Ceará realizado pelos próprios alunos. Em três edições, o NoAr formaria mais de 100 jovens. Além de Victor de Melo, despontariam a partir dessa iniciativa vários realizadores de audiovisual em atividade no estado, como Marco Rudolf, Kiko Alves, Claugeane Costa, Eudes Freitas, dentre outros. Sobre o assunto, ver: Barbalho, 2007.

5 A Vila das Artes foi um projeto que nasceu em 2006 por iniciativa da Fundação de Cultura da Prefeitura Municipal de Fortaleza, contando com várias parcerias, dentre elas a Universidade Federal do Ceará. Localizado em um prédio histórico do centro da cidade, passou a reunir inicialmente a escola de audiovisual, os pontos de corte, a escola de dança, o núcleo de produção digital e cursos livres de curta duração.

6 Dando continuidade a essa linha fílmica, o realizador já realizou vários ensaios fotográficos na Praia de Iracema, Ponte Metálica e Poço da Draga. Em 2016 ele colaborou com o filme dirigido por Pedro Diógenes intitulado Fort Aquário, documentário todo realizado com as fotografias de Victor de Melo.

7 Popularmente conhecida como "beco da apertada hora", a Rua Governador Sampaio também já foi chamada de Rua Nova do Outeiro. Ver: Lopes, 2010.

8 Victor de Melo também assina a edição, juntamente com Frederico Benevides. A equipe completa escolhida para fazer o filme possui apenas sete pessoas. $\mathrm{Na}$ época das gravações, todos eles estudavam na Escola de Audiovisual de Fortaleza. Esse debate sobre a 
formação dos realizadores do estado é importantíssimo, principalmente em se tratando dessa geração mais jovem de cineastas, sendo decisiva e determinante para os rumos tomados pela produção local, nas oportunidades que surgiram e nas escolhas realizadas por essa nova cena contemporânea cearense.

9 O zoom é um recurso de aproximação (no caso do zoom-in) e de distanciamento (no caso do zoom-out) de qualquer elemento de uma cena até a lente da câmera.

\section{Referências}

AGAMBEN, G. O que é o contemporâneo? E outros ensaios. Chapecó: Ed. Argos, 2009.

BARBALHO, A. Jovens com ideia na cabeça e câmera na mão: biopolítica e trabalho imaterial na produção audiovisual. Revista Cinética, v. 1, p. 1-14, 2007.

BORZACCHIELLO, J. Opinião: Becos da cidade. Jornal O Povo. 8 maio 2010. Disponível em: $\quad<$ http://www.opovo.com.br/app/opovo/ opiniao/2010/05/08/noticiasjornalopiniao,981604/ becos-da-cidade.shtml>. Acesso em: 30 out. 2016.

CALVINO, Í. As cidades invisíveis. São Paulo: Companhia das Letras, 1990.

COMOLLI, J-L. Ver e poder - a inocência perdida: cinema, televisão, ficção, documentário. Belo Horizonte: Ed. UFMG, 2008.

DIÁRIO DO NORDESTE. Cidade: Poço da Draga comemora 108 anos. 27 maio 2014. Disponível em: <http://diariodonordeste.verdesmares.com.br/ cadernos/cidade/poco-da-draga-comemora-108anos-1.1023682>. Acesso em: 30 out. 2016.

LOPES, M. Tirada do Baú: Ruas de antigamente. Jornal Diário do Nordeste. 18 de dez. 2010. Disponível em: <http://diariodonordeste. verdesmares.com.br/suplementos/gente/coluna/ tirada-do-bau-1.180/mata-ria-904203-1.736011>. Acesso em: 30 out. 2016.

PESAVENTO, S. J. Cidades visíveis, cidades sensíveis, cidades imaginárias. Revista Brasileira de História, São Paulo, v. 27, n. 53, p. 11-23, 2007.

RANCIĖRE, J. O espectador emancipado. Lisboa: Orfeu Negro, 2010.

RUA Governador Sampaio. Diretor: Victor de Melo. Co-produção: Caroline Louise, Rubia Mercia, Ythallo Rodrigues. Fotografia: Victor de Melo. Empresa(s) produtora(s): Alumbramento Produções Cinematográficas. Mini-DV (13 min), son., color., 2009. Disponível em: <https://www. youtube.com/watch? $\mathrm{v}=\mathrm{a} 4 \mathrm{PHgzZpTvI}>$. Acesso em: 30 out. 2016.

TARKOVSKY, A. Esculpir o tempo. São Paulo: Martins Fontes, 1998.

WILLIAMS, R. O campo e a cidade: na história e na literatura. São Paulo: Companhia das Letras, 1989. 